\title{
The Factor of Family Support Towards the Success of Tuberculosis Therapy: A Cohort Study
}

\author{
$1^{\text {st }}$ Tri Pitara Mahanggoro \\ Department of Physiology, Faculty of \\ Medicine and Health Science \\ Universitas Muhammadiyah \\ Yogyakarta (UMY) \\ Yogyakarta, Indonesia \\ mastripitara@yahoo.com
}

\author{
$2^{\text {nd }}$ Noor Aulia Fajriyati \\ Faculty of Medicine and Health Science \\ Universitas Muhammadiyah \\ Yogyakarta (UMY) \\ Yogyakarta, Indonesia \\ nauliaf@ymail.com
}

\author{
$3^{\text {rd }}$ Iffa Karina Permatasari \\ Faculty of Medicine, Public Health and \\ Nursing \\ Universitas Gadjah Mada (UGM) \\ Yogyakarta, Indonesia \\ iffakarinap@gmail.com
}

\begin{abstract}
Indonesia ranks second in the world regarding tuberculosis after India. Tuberculosis (TB) is a disease that can be cured if treatment is carried out quickly and precisely. Factors related to adherence to treatment, duration of treatment, socioeconomic, nutritional status, smoking habits, and professions at risk correlate with the success of TB therapy. The purpose of this study was to determine whether family support capacity associated with the success of TB therapy. Methods: This study used a cohort prospective design. The subjects of this study were 57 patients with pulmonary and extrapulmonary tuberculosis patients. Primary data were collected using standardized questionnaires. Patients' medical records were recorded for secondary data. Risk ratio, p-value, and $95 \%$ confidence interval were calculated using chi-square analysis. Results: The results of the analysis showed that a good family carrying capacity increased the success of tuberculosis therapy with a value of $\mathbf{p}<0,0001$ while the Relative Risk $(R R)$ analysis obtained a value of 5.4 indicating good family support capacity could increase 5.4 times the success of tuberculosis therapy. Conclusion: Family support is needed in tuberculosis therapy as it can increase the success of tuberculosis therapy.
\end{abstract}

Keywords-tuberculosis, family support, cohort, therapy success

\section{INTRODUCTION}

Tuberculosis (TB) is an infectious disease that can be transmitted and caused by Mycobacterium tuberculosis, which can attack various organs. The World Health Organization states that tuberculosis (TB) is a global public health emergency. Globally in 2015, it was estimated that there were 10.4 million cases of tuberculosis (TB) (range, 8.7 million to 12.2 million) in which Indonesia was ranked number two in the world after India was followed by China in third place. These three countries are $45 \%$ of contributors to global tuberculosis (TB) cases in the world in 2015 [1].

The WHO Global Tuberculosis Report 2015 mentions estimates TB incidence in Indonesia ranges from 658-1450 thousand incidents where the prevalence survey in Indonesia is now estimated that there are around 1 million new TB cases per year in Indonesia, twice the previous estimate and increasing every year. The surge in tuberculosis (TB) will have several impacts, such as a decrease in the quality of life, social, economic and environmental impacts. The incidence of tuberculosis (TB) surged due to several factors, including the failure of TB therapy which can lead to a greater risk of tuberculosis because it will cause relapse or immune to Anti Tuberculosis Drugs [2]. Almost three of four pulmonary tuberculosis patients who defaulted from their TB therapy still had their sputum sample smear-positive for TB. This can highly lead to transmission to others [3], [4].

Tuberculosis (TB) is a disease that can be cured if treatment is carried out quickly and precisely. Tuberculosis patients who do not recover or do not get treatment completely and correctly do not only pose a serious risk to individuals and the community [5]. Failure of Anti Tuberculosis Drugs therapy can result in the emergence of multidrug-resistant TB (MDR-TB), prolonged infection and poor results of TB treatment.

Tuberculosis (TB) therapy is generally divided into 2 stages, namely the initial and advanced stages. Where this initial stage focuses on reducing the symptoms of TB and decreasing the transmission rate and the advanced stage for killing remnants of germs. The time taken to Tuberculosis treatment for primary patients or who have recently been exposed to TB is about 6 to 9 months. The success of TB therapy in terms of treatment results and supporting examinations, where at the time the treatment ends a negative bacteriological test (BTA) or in one previous test and can also be proven by chest radiology [6].

Non-compliance with tuberculosis treatment at a health care facility is one of the obstacles in achieving a high success rate of tuberculosis treatment. Adherence to treatment factors, duration of treatment, socioeconomic, nutritional status, smoking habits, and occupation is associated with the success of TB therapy [7].

Family support for people with tuberculosis (TB) is very important. The family is also the first line as the person closest to the patient. Tuberculosis (TB) treatment given by family members, the treatment success is higher than that given by non-family members [8]. Family support is one factor in the success of tuberculosis (TB) therapy due to financial difficulties both money and time, difficulty in health facilities, unable to do the routine treatment every day without the help of other people, especially women [9]. Patients' desire to be cured and will to complete treatment can come from family, neighbors, doctors, and patients themselves. Family and 
closest relatives are people who the patient was first notified and trusted to tell the diagnosis because he felt that there was an attachment to the mind and the basic life of the patient was much influenced by his family and closest relatives. Other driving factors include wanting to recover, fear of complication and death, improvement after starting treatment, seeing patients recover and family support [10].

Family support is the most important thing in resolving the problem of preventing tuberculosis (TB) transmission. Family support will increase motivation and self-confidence to behave for preventing transmission of Tuberculosis. With the power of family support which is the first line of supporting the patient for the successful treatment of tuberculosis (TB) so that patients can achieve healing. This study was conducted with the aim to determine whether family support capacity associated with the success of TB therapy.

\section{METHODS}

This study uses a non-experimental design with the Cohort Study approach. The study was conducted for six months for pulmonary TB and nine months for extrapulmonary TB. Data collection started in May 2017.

\section{A. Study subject}

The population of this study was tuberculosis patients undergoing therapy of tuberculosis. The number of respondents is 57 respondents from three different hospitals. The hospitals were PKU Muhammadiyah Gamping Hospital, PKU Muhammadiyah Yogyakarta Hospital, and Respira Lung Hospital. Inclusion criteria in this study were patients with age of at least 12 years old, newly diagnosed tuberculosis patients and were about to just undergo therapy. We excluded patients who have a complication, drop out of the therapy, did not answer the questionnaire completely, and patients who were transferred out to another city where the original hospital was not able to find out the outcome of the therapy.

\section{B. Variables}

Variables in this study were family support, the success of tuberculosis therapy, age, gender, occupation, highest education, duration of tuberculosis therapy, and the type of tuberculosis. Family support capacity in this study was defined as a patient's perception of the support received and felt by all family members that was measured based on emotional, informative, appreciation and instrumental aspects. Family support capacity was assessed using a validated questionnaire with 18 questions that used the Likert scale. The reliability of this questionnaire was tested with a Cronbach Alpha value of 0.964 .

The success of tuberculosis therapy in this study was defined as tuberculosis patients who were healed or completed the therapy. The criteria of healed tuberculosis patients were patients with a positive bacteriological test at the beginning that has a negative bacteriological test at the end of the treatment, and in one of the bacteriological tests before the end of treatment. Tuberculosis therapy is considered unsuccessful if the patient's therapy fails, namely when the patient whose sputum examination results remain positive or return to be positive in the fifth month or more during treatment or at any time if during the treatment obtained laboratory results that indicate the presence of Anti Tuberculosis Medication retention.

\section{Data collection and analysis}

The data collected by interviewing respondents using the questionnaire as primary data and the medical record as secondary data. Data on respondents' characteristics such as age, gender, occupation, and highest education were also collected to get the distribution of tuberculosis patients in this study by sociodemographic characteristics. Data then were analyzed using the Chi-square test to determine the association between the variables. We calculated relative risk (RR) and obtained p-value and 95\% confidence interval.

\section{Ethics}

This study has received ethical clearance from the ethics committee of the Faculty of Medicine and Health Science, Universitas Muhammadiyah Yogyakarta, Indonesia.

\section{RESULTS AND DISCUSSION}

At the beginning of the study, we were able to include 66 patients from three hospitals as respondents. One patient died and one patient was transferred to another city. Six patients were lost to follow up, and one patient rejected to be interviewed at the end of the follow-up period. Eventually, there were a total of 57 patients that completed this study.

\section{A. Characteristics of Subjects}

Descriptive analysis was done to determine the distribution of patients based on age, gender, occupation, highest education and tuberculosis-related characteristics such as duration of treatment, the success of therapy, and type of TB. The result of the descriptive analysis is shown in table 1.

TABLE I. CHARACTERISTICS OF SUBJECTS

\begin{tabular}{|c|c|c|}
\hline Characteristics & $n$ & $\%$ \\
\hline \multicolumn{3}{|l|}{ Age } \\
\hline Late Youth & 12 & 21.1 \\
\hline Early Adult & 16 & 28.1 \\
\hline Late adults & 5 & 8.8 \\
\hline Early Elderly & 9 & 15.8 \\
\hline Late Elderly & 10 & 17.5 \\
\hline Old man & 5 & 8.8 \\
\hline \multicolumn{3}{|l|}{ Gender } \\
\hline Male & 35 & 61.4 \\
\hline Female & 22 & 38.6 \\
\hline \multicolumn{3}{|l|}{ Occupation } \\
\hline Unemployed & 12 & 21.1 \\
\hline Farmers/laborers & 8 & 14.0 \\
\hline Private & 9 & 15.8 \\
\hline Civil servants & 6 & 10.5 \\
\hline Student & 10 & 17.5 \\
\hline Entrepreneur & 10 & 17.5 \\
\hline Other & 2 & 3.5 \\
\hline \multicolumn{3}{|l|}{ Highest education } \\
\hline Not completed in primary school & 1 & 1.8 \\
\hline
\end{tabular}




\begin{tabular}{|c|c|c|}
\hline Characteristics & $n$ & $\%$ \\
\hline Elementary school & 10 & 17.5 \\
\hline Junior high school & 6 & 10.5 \\
\hline High school & 32 & 56.1 \\
\hline Higher education & 8 & 14.0 \\
\hline Duration of treatment & & \\
\hline 6 months & 55 & 96.5 \\
\hline 9 months & 2 & 3.5 \\
\hline Success of therapy & 47 & 82.5 \\
\hline Succeeded & 10 & 17.5 \\
\hline Has not succeeded & & \\
\hline Type of TB & 47 & 82.5 \\
\hline Pulmonary & 10 & 17.5 \\
\hline Extrapulmonary & \multicolumn{2}{c|}{${ }^{\text {a. Chi-square test }}$} \\
\hline
\end{tabular}

TABLE II. RESPONDENTS' CHARACTERISTICS IN THE FIRST MONTH OF THERAPY AS FACTORS OF TUBERCULOSIS THERAPY SUCCESS.

\begin{tabular}{|c|c|c|c|c|}
\hline \multirow[b]{2}{*}{ Variables } & \multicolumn{2}{|c|}{ Success of therapy } & \multirow[b]{2}{*}{$p^{a}$} & \multirow[b]{2}{*}{$\begin{array}{c}R R \\
(95 \% C I)\end{array}$} \\
\hline & $\begin{array}{l}\text { Success } \\
n(\%)\end{array}$ & $\begin{array}{c}\text { Not } \\
\text { successful } \\
n(\%)\end{array}$ & & \\
\hline Age & & & 0.395 & $\begin{array}{c}1.50 \\
(0.282- \\
0.701)\end{array}$ \\
\hline Late Youth & $11(19.3)$ & $1(1.8)$ & & \\
\hline Early Adult & $13(22.8)$ & $3(5.3)$ & & \\
\hline Late adults & $4(7.0)$ & $1(1.8)$ & & \\
\hline Early Elderly & $8(14.0)$ & $1(1.8)$ & & \\
\hline Late Elderly & $7(12.3)$ & $3(5.3)$ & & \\
\hline Old man & $4(7.0)$ & $1(1.8)$ & & \\
\hline Gender & & & 0.920 & $\begin{array}{c}1.07 \\
(0.266- \\
4.335) \\
\end{array}$ \\
\hline Male & $29(50.9)$ & $6(10.5)$ & & \\
\hline Female & $18(31.6)$ & $4(7.0)$ & & \\
\hline Occupation & & & 0.539 & $\begin{array}{c}1.58 \\
(0.854- \\
1.365) \\
\end{array}$ \\
\hline Unemployed & $19(33.3)$ & $3(5.3)$ & & \\
\hline Employed & $28(49.1)$ & $7(12.3)$ & & \\
\hline Highest education & & & 0.989 & $\begin{array}{c}0.99 \\
(0.223- \\
4.392) \\
\end{array}$ \\
\hline Low level & $14(24.6)$ & $3(5.3)$ & & \\
\hline High level & $33(57.9)$ & $7(12.3)$ & & \\
\hline Type of TB & & & 0.490 & $\begin{array}{c}0.47 \\
(0.700- \\
1.152) \\
\end{array}$ \\
\hline Pulmonary & $38(66.7)$ & $9(15.8)$ & & \\
\hline Extrapulmonary & $9(15.9)$ & $1(1.8)$ & & \\
\hline $\begin{array}{l}\text { Early Family } \\
\text { Support Capacity }\end{array}$ & & & $<0.001$ & $\begin{array}{c}69.0 \\
(6.576- \\
723.978)\end{array}$ \\
\hline Good & $46(80.7)$ & $5(8.8)$ & & \\
\hline Not good & $1(1.8)$ & $5(8.8)$ & & \\
\hline
\end{tabular}
male and the most age group was early adulthood. More male than female respondents in this study was due to the trend in lifestyle factors of men who smoke and drink alcoholic beverages. This is consistent with research which stated that pulmonary TB sufferers tend to be higher in men because more men have the ability to smoke [11]. Cigarettes and alcoholic drinks can reduce the body's immune system, so it is susceptible to pulmonary TB [12]. In addition, most men work outside the home so that the possibility of contracting TB germs is greater [13]. This is consistent with surveillance evidence from WHO related to the incidence of tuberculosis based on age and sex which states that the highest TB disease incidence is in the 15-34 age category with the male sex greater than women [14].

Most of the respondents' work was unemployment. A large number of respondents who do not work can show a low economic level and it is closely related to tuberculosis. One of the main causes of the burden of the tuberculosis problem is poverty in various community groups related to sanitation, clothing, food, poor housing [6].

By the highest education, respondents were dominated by high school graduates. Education is related to patient knowledge and affects the success of a patient's treatment. Knowledge is very important for the formation of one's actions, behavior based on knowledge will be more lasting than behavior that is not based on knowledge. The higher the level of education, the better the reception of information about treatment and illness so that the treatment process and treatment will be more complete, including tuberculosis [15]. Based on tuberculosis-related characteristics, most of this study respondents were pulmonary tuberculosis patients who underwent treatment for 6 months and successfully underwent tuberculosis therapy.

\section{B. Factors of Tuberculosis Therapy Success}

In order to determine factors that led to the success of tuberculosis therapy, a chi-square test was used and risk ratio alongside $\mathrm{p}$-value and 95\% confidence interval were calculated. The results of the analysis by the data collected in the first month of therapy can be seen in table 2 .

As shown in table 2, it is known that almost all patients with successful tuberculosis therapy received good early family support capacity or in the first month of therapy. We also analyzed the condition of tuberculosis patients with the success of tuberculosis therapy. The results of the analysis were shown in table 3 . 
TABLE III. RESPONDENTS' SYMPTOMS WITH SUCCESS OF TUBERCULOSIS THERAPY.

\begin{tabular}{|c|c|c|c|c|}
\hline \multirow[b]{2}{*}{ Variables } & \multicolumn{2}{|c|}{ Success of therapy } & \multirow[b]{2}{*}{$p^{a}$} & \multirow[b]{2}{*}{$\begin{array}{c}R R \\
(95 \% C I)\end{array}$} \\
\hline & $\begin{array}{c}\text { Success } \\
n(\%)\end{array}$ & $\begin{array}{c}\text { Not } \\
\text { successful } \\
n(\%)\end{array}$ & & \\
\hline Cough & & & 0.809 & $\begin{array}{c}1.32 \\
(0.141- \\
12.329) \\
\end{array}$ \\
\hline Yes & $6(10.5)$ & $1(12.3)$ & & \\
\hline No & $41(71.9)$ & $9(15.8)$ & & \\
\hline Sputum & & & 0.402 & $\begin{array}{c}4.95 \\
(0.948- \\
25.858) \\
\end{array}$ \\
\hline Yes & $21(36.8)$ & $8(14.0)$ & & \\
\hline No & $26(45.6)$ & $2(3.5)$ & & \\
\hline Fever & & & 0.345 & $\begin{array}{c}0.36 \\
(0.041- \\
3.196)\end{array}$ \\
\hline Yes & $11(19.3)$ & $3(5.3)$ & & \\
\hline No & $36(63.2)$ & $7(12.3)$ & & \\
\hline Weight Loss & & & 0.906 & $\begin{array}{c}0.91 \\
(0.207- \\
4.037) \\
\end{array}$ \\
\hline Yes & $15(26.3)$ & $2(3.5)$ & & \\
\hline No & $32(56.1)$ & $8(14.0)$ & & \\
\hline Chest Pain & & & 0.822 & $\begin{array}{c}1.22 \\
(0.217- \\
6.848)\end{array}$ \\
\hline Yes & $8(14.0)$ & $4(7.0)$ & & \\
\hline No & $39(66.4)$ & $6(10.5)$ & & \\
\hline $\begin{array}{l}\text { Breathing } \\
\text { Difficulties }\end{array}$ & & & 0.622 & $\begin{array}{c}1.42 \\
(0.349- \\
5.802)\end{array}$ \\
\hline Yes & $15(26.3)$ & $4(7.0)$ & & \\
\hline No & $32(56.1)$ & $6(10.5)$ & & \\
\hline $\begin{array}{l}\text { Symptoms } \\
\text { Improvement }\end{array}$ & & & 0.355 & $\begin{array}{c}1.94 \\
(0.468- \\
8.084)\end{array}$ \\
\hline Yes & $35(61.4)$ & $6(10.5)$ & & \\
\hline No & $12(21.1)$ & $4(7.0)$ & & \\
\hline
\end{tabular}

Table 3 shows the condition of tuberculosis patients with successful tuberculosis therapy. In addition to improved laboratory tests, clinical conditions also improved. The clinical condition is not experiencing coughing, phlegm, fever, weight loss, shortness of breath, and chest pain.

\section{Family Support as A Factor to Achieve Tuberculosis Therapy Success}

Family support as a factor of tuberculosis therapy success was analyzed using the Chi-square test to obtain relative risk (RR) and 95\% confidence interval $(95 \% \mathrm{CI})$. Results of the analysis done for family support were shown in table 4 .
TABLE IV. FAMILY SUPPORT AS A FACTOR OF TUBERCULOSIS THERAPY SUCCESS

\begin{tabular}{|c|c|c|c|c|}
\hline \multirow[b]{2}{*}{ Variables } & \multicolumn{2}{|c|}{ Success of therapy } & \multirow[b]{2}{*}{$p^{a}$} & \multirow[b]{2}{*}{$\begin{array}{c}R R \\
(95 \% C I)\end{array}$} \\
\hline & $\begin{array}{c}\text { Success } \\
n(\%)\end{array}$ & $\begin{array}{c}\text { Not } \\
\text { successful } \\
n(\%)\end{array}$ & & \\
\hline \multicolumn{5}{|l|}{$\begin{array}{l}\text { Early (First } 1 \\
\text { month) }\end{array}$} \\
\hline Good & $46(80.7)$ & $4(7.0)$ & $<0.001$ & $\begin{array}{r}69.00 \\
(6.576- \\
723.978) \\
\end{array}$ \\
\hline Not good & $1(1.8)$ & $6(10.5)$ & & \\
\hline \multicolumn{5}{|l|}{$\begin{array}{l}\text { Family support } \\
\text { for } 6 \text { or } 9 \text { months }\end{array}$} \\
\hline Good & $46(80.7)$ & $5(8.8)$ & $<0.001$ & $\begin{array}{c}46.00 \\
(4.444- \\
476.105)\end{array}$ \\
\hline Not good & $1(1.8)$ & $5(8.8)$ & & \\
\hline
\end{tabular}

The results of the chi-square test in table 4 showed that good early family support significantly associated with the success of tuberculosis therapy $(\mathrm{p}<0.05)$. Compared to the patient with poor early family support, tuberculosis patient with good early family support or good family support received within the first month of therapy has 69 times higher chance in succeeding the therapy. Patient with good family support throughout the tuberculosis therapy also has 46 times higher chance of achieving therapy success compared to the patient with poor family support, with a significant association.

Family and social support interventions for tuberculosis patients have been recommended by WHO as a management program for tuberculosis therapy and become a strategy to prevent drug resistance [14]. The family plays a supportive role during the therapy, healing, and recovery of the patient. If there is no such support, the success of therapy, healing or recovery is greatly reduced [10], [16]. Family can assist patients in daily routine activities, taking medication, give financial support and motivational or emotional support to finally complete the tuberculosis therapy [9], [17], [18].

Lack of support is one of the main causes of noncompliance among Tuberculosis patients thus reducing the success rate of therapy. Other studies say many tuberculosis patients who do not get family support are forced to seek support both financially and emotionally themselves so that patients feel worthless and fatigue in their daily lives and in treatment [19]. Social support and family support are found to be the main driving factors for completing tuberculosis therapy. Attention and support from family, environment, neighbors and the community are the most important driving factors for tuberculosis patients to complete and carry out therapy so they can recover [20]. Lack of social support for most patients is an important factor for matters relating to adherence, stigma, effects, and duration of treatment. Support is an important factor for triggering other things that help the success of therapy [21], [22].

Support from family was very necessary by patients to support the healing process and therapy. Such support is like reminding to conduct a re-examination, reminding to take medicine, a comfortable living environment, daily needs and nutrition that is considered. In a study stated that if family 
support such as reminding to always take medicine, paying attention to the schedule of routine examinations will make patients better in therapy [17]. A cluster randomized controlled trial in Ethiopia tried to give psychological counseling and adherence education TB patients. Unmarried TB patients have a higher chance of getting non-adherence to TB treatment compared to married TB patients. Even one family member can make a change in TB treatment adherence, furthermore, treatment success [15].

Tuberculosis patients who are the main breadwinners in most families have negative results between family support and successful therapy. Patients feel irresponsible and cannot provide what a breadwinner should give. Patients tend to feel guilty and feel embarrassed so that the family is expected to help patients not to feel like these things [23]. In addition, the most needed thing from family support is emotional support compared to material and instrumental support even though both are needed. This is in line with a study conducted in Ghana, where the most important thing is the family's love and attention [24].

\section{CONCLUSION}

Family support is needed in tuberculosis therapy as it can increase the success of tuberculosis therapy. Both family support for the first month of therapy and family support for 6 or 9 months of therapy significantly associated with the success of tuberculosis therapy. Patient with good family support throughout the tuberculosis therapy has 46 times higher chance of achieving therapy success. Hospitals and health workers should educate both patients and patients' families that family support can increase the success of therapy that can reduce patients who are drug-resistant.

\section{ACKNOWLEDGMENT}

We acknowledge the support from Universitas Muhammadiyah Yogyakarta, Indonesia.

\section{REFERENCES}

[1] World Health Organization, 'Global Tuberculosis Report 2016', Geneva, 2016.

[2] World Health Organization, 'Global Tuberculosis Report', Geneva, 2015.

[3] A. Arnold et al., 'Drug Resistant TB: UK Multicentre Study (DRUMS): Treatment, Management and Outcomes in London and West Midlands 2008-2014', J. Infect., vol. 74, no. 3, pp. 260-271, 2017.

[4] K. Dheda et al., 'The epidemiology, pathogenesis, transmission, diagnosis, and management of multidrug-resistant, extensively drugresistant, and incurable tuberculosis', Lancet Respir. Med., vol. 5, no. 4, pp. 291-360, 2017.

[5] J. Karumbi and P. Garner, 'Directly observed therapy for treating tuberculosis (Review)', Cochrane Database Syst. Rev., no. 5, 2015.

[6] Indonesia Ministry of Health, Regulation of the Minister of Health of the Republic of Indonesia Number 67 Year 2016 Regarding Tuberculosis Management [Peraturan Menteri Kesehatan Republik Indonesia Nomor 67 Tahun 2016 Tentang Penanggulangan Tuberkulosis]. Jakarta: Indonesia Ministry oh Health, 2016.

[7] M. K. Ali, S. Karanja, and M. Karama, 'Factors associated with tuberculosis treatment outcomes among tuberculosis patients attending tuberculosis treatment centres in 2016-2017 in Mogadishu, Somalia', Pan Afr. Med. J., vol. 28, pp. 1-14, 2017.

[8] P. V. Dave et al., 'Direct observation of treatment provided by a family member as compared to non-family member among children with new tuberculosis: A pragmatic, non-inferiority, cluster-randomized trial in Gujarat, India', PLoS One, vol. 11, no. 2, pp. 1-14, 2016.

[9] T. Hidayati et al., 'Factors that Affct the Success of Tuberculosis Therapy in Primary Care: Type of Tb Preliminary Studies', Indian J. Public Heal. Res. Dev., vol. 10, no. 3, pp. 872-876, 2019.

[10] N. Melizza, R. Hargono, and Makhfudli, 'Role of family members in the treatment of tuberculosis patients: a systematic review', in The 9th International Nursing Conference 2018 "Nurses at The Forefront in Transforming Care, Science, and Research, 2018, pp. 680-682.

[11] S. Nandasena, C. Senavirathna, C. Munasinghe, C. Wijesena, and R. Sucharitharathna, 'Characteristics and sputum conversion of tuberculosis (TB) patients in Kalutara, Sri Lanka', Indian J. Tuberc., vol. 66, no. 1, pp. 76-80, 2019.

[12] L. E. Gleeson, S. M. O. Leary, D. Ryan, A. M. Mclaughlin, F. J. Sheedy, and J. Keane, 'Cigarette Smoking Impairs the Bioenergetic Immune Response to Mycobacterium tuberculosis Infection', Am. J. Respir. Cell Mol. Biol., vol. 59, no. 5, pp. 572-579, 2018.

[13] D. Husnaniyah, 'Hubungan Dukungan Keluarga Dengan Harga Diri (Self Esteem) Penderita Tuberkulosis Paru di Wilayah Eks Kawedanan Indramayu [Association of Family Support with Self Esteem of Pulmonary Tuberculosis Patients in The Area of Eks Kawedanan Indramayu]', J. Kesehat. INdra Husada, vol. 5, no. 1, pp. 32-39, 2017.

[14] World Health Organization, 'Global Tuberculosis Report 2018', Geneva, 2018

[15] H. H. Tola, A. Tol, and D. Shojaeizadeh, 'Tuberculosis Treatment Non-Adherence and Lost to Follow Up among TB Patients with or without HIV in Developing Countries : A Systematic Review', Iran J. Public Heal., vol. 44, no. 1, pp. 1-11, 2015.

[16] S. SeyedAlinaghi et al., 'Adherence to Antiretroviral Therapy and Tuberculosis Treatment in a Prison of Tehran, Iran', Infect. Disord. Drug Targets, vol. 16, no. 3, pp. 1-5, 2016.

[17] N. M. Irnawati, I. E. T. Siagian, and R. I. Ottay, 'Pengaruh dukungan keluarga terhadap kepatuhan minum obat pada penderita tuberkulosis di Puskesmas Motoboi Kecil Kota Kotamobagu [The influence of family support for treatment adherence in tuberculosis patients at the Motoboi Kecil Public Health Center in ', J. Kedokt. Komunitas dan Trop., vol. IV, no. 1, pp. 59-64, 2016.

[18] M. Mehari, N. Kiros, A. Yemane, N. Asghedom, S. Debesay, and T. Tekeste, 'Factors Affecting Treatment Adherence among HIVPositive Patients in Eritrea', Int. Biol. Biomed. J., vol. 3, no. 3, pp. 150-156, 2017

[19] F. H. Gebreweld et al., 'Factors influencing adherence to tuberculosis treatment in Asmara, Eritrea: a qualitative study', J. Health. Popul. Nutr., vol. 37, no. 1, p. 1, 2018

[20] R. D. Deshmukh, D. J. Dhande, K. S. Sachdeva, A. N. Sreenivas, A. M. V. Kumar, and M. Parmar, 'Social support a key factor for adherence to multidrug-resistant tuberculosis treatment', Indian $J$. Tuberc., vol. 65, no. 1, pp. 41-47, 2018.

[21] R. Van Hoorn, E. Jaramillo, D. Collins, A. Gebhard, and S. Van Den Hof, 'The Effects of Psycho-Emotional and Socio- Economic Support for Tuberculosis Patients on Treatment Adherence and Treatment Outcomes - A Systematic Review and Meta- Analysis', PLoS One, vol. 11, no. 4, p. e0154095, 2016

[22] C. Gugssa Boru, T. Shimels, and A. I. Bilal, 'Factors contributing to non-adherence with treatment among TB patients in Sodo Woreda, Gurage Zone, Southern Ethiopia: A qualitative study', J. Infect. Public Health, vol. 10, no. 5, pp. 527-533, 2017

[23] S. van den Hof, D. Collins, F. Hafidz, D. Beyene, A. Tursynbayeva, and E. Tiemersma, 'The socioeconomic impact of multidrug resistant tuberculosis on patients: Results from Ethiopia, Indonesia and Kazakhstan', BMC Infect. Dis., vol. 16, no. 1, 2016.

[24] T. Nottingham and N. E. User, "“ Ghost" stories : sociocultural factors influencing tuberculosis treatment adherence in Ghana', Nottingham, PHC1159R1 Article, 2016. 